\title{
Relation between magnesium and calcium and parameters of pain, quality of life and depression in women with fibromyalgia
}

\author{
Aline Andretta ${ }^{1 *} \mathbb{D}$, Emmanuelle Dias Batista ${ }^{1}$, Maria Eliana Madalozzo Schieferdecker ${ }^{2}$, \\ Ricardo Rasmussen Petterle ${ }^{3}$, César Luiz Boguszewski ${ }^{4}$ and Eduardo dos Santos Paiva ${ }^{5}$
}

\begin{abstract}
Objective: Determine food intake and levels of serum magnesium (Mg) and calcium (Ca) and correlate these minerals with pain, quality of life and depression risk in women with and without fibromyalgia (FM).

Patients and methods: Fifty-three women diagnosed with FM and 50 healthy women participated in the study, where all of them had equivalent age and body mass index (BMI). All women underwent anthropometric assessment, physical exams of pain perception threshold and tender point (TP) count, blood sample collection, and filling out of FM impact questionnaire (FIQ), Patient Health Questionnaire-9 (PHQ-9), and 3-day dietary record (DR).

Results: Dietary intake of $\mathrm{Mg}$ and Ca was substantially lower by women with FM. There were no differences in levels of serum Mg and $\mathrm{Ca}$ in the groups under analysis. For the FM group, dietary intake of $\mathrm{Mg}$ and Ca had inverse correlation with TP and direct relation with the pain threshold.

Conclusions: Although women with FM had lower dietary intake of Mg and $\mathrm{Ca}$, serum levels for these nutrients were not different between the groups. Low dietary intake of minerals correlated with worsened pain threshold parameters.
\end{abstract}

Keywords: Fibromyalgia, Magnesium, Calcium, Pain, Quality of life

\section{Introduction}

Fibromyalgia (FM) is a complex chronic syndrome of unknown etiology characterized by profound, disseminated pain, sleep disorders, cognitive impairment, fatigue, and other functional symptoms. Recently, it has been suggested that an unbalance of dietary components including metallic ions and vitamins may play a major role in the development of FM [1].

Several research studies have shown that patients with chronic pain do not follow the recommended dietary intake of most vitamins and minerals [2-5]; and such deficiencies have been associated to several pathological conditions of chronic pain, including FM [1, 3, 4].

Additionally, studies have investigated the impact of magnesium $(\mathrm{Mg})$ on pain improvement $[4,6-9]$. $\mathrm{Mg}$ is

\footnotetext{
* Correspondence: alineandretta@hotmail.com

${ }^{1}$ Departamento de Medicina Interna, Universidade Federal do Paraná,

Hospital de Clínicas, Rua General Carneiro, 181, Curitiba, PR 80060-900, Brazil Full list of author information is available at the end of the article
}

an important trace element for many metabolic functions, also vital for the activity of over 300 enzymes [6]. Mg deficiency has been associated to headache, migraine, fibromyalgia, increase in C-reactive Protein (CRP), osteoporosis, cardiovascular disease, and other conditions [10].

Magnesium acts by inhibiting several nerve receptors, such as N-methyl-D-aspartate (NMDA), which relate to the origin of certain types of FM pain $[11,12] . \mathrm{Mg}$ blocks $\mathrm{Ca}$ channels, including the channel of NMDA receptors, and that could probably explain its analgesic effect [13]. When Mg is deficient, it is possible to notice increase in the activity of the NMDA receptor [14], as well as Substance P, which may lead to increased pain and higher levels of hormones related to stress [7].

$\mathrm{Mg}$ plays a major role also in FM, given that several manifestations of this condition, such as fatigue, muscle weakness, irritable bowel, and paresthesia are similar to the symptoms of deficiency in Mg [4]. Moreover, such

(c) The Author(s). 2019 Open Access This article is distributed under the terms of the Creative Commons Attribution 4.0 International License (http://creativecommons.org/licenses/by/4.0/), which permits unrestricted use, distribution, and reproduction in any medium, provided you give appropriate credit to the original author(s) and the source, provide a link to the Creative Commons license, and indicate if changes were made. The Creative Commons Public Domain Dedication waiver (http://creativecommons.org/publicdomain/zero/1.0/) applies to the data made available in this article, unless otherwise stated. 
deficiency may have a shared link among stress, inflammation and metabolic syndrome, which may cause an inappropriate response with the activation of intracellular calcium (Ca) [2].

$\mathrm{Mg}$ frequently acts as natural antagonist of $\mathrm{Ca}$ [15]. While $\mathrm{Ca}$ acts as stimulator of muscle contraction, $\mathrm{Mg}$ acts as relaxant [16]. These two cations compete for the modulation of muscle contraction and regulate several enzymatic reactions involved in energetic metabolism, in signal transduction, and in brain activity [17].

It is not yet a consensus in the literature whether serum levels and dietary intake of $\mathrm{Mg}$ and $\mathrm{Ca}$ may be correlated with FM signs and symptoms. Therefore, this study aims to determine the food intake and serum levels of magnesium and calcium, and correlate these minerals to pain, quality of life and depression risk in women with and without fibromyalgia.

\section{Materials and methods}

A cross-sectional research study was performed between March and October 2012, and approved by the Research Ethics Committee of the Hospital de Clínicas of the Federal University of Paraná (HC/UFPR). The study analyzed women in ages between 18 to 60 years, selected at the Rheumatology Outpatient Clinic at the HC/UFPR, who had been diagnosed with FM according to criteria set forth by the American College of Rheumatology (ACR) in 1990 [18]. The reason for including only women in the study was the low prevalence of fibromyalgia among men. The control group consisted of women with the same age span who did not have FM and other associated clinical conditions.

Patients with fibromyalgia and depression or anxiety were only included if their treatment had remained unchanged for 3 months. The exclusion criteria were: use of calcium and magnesium supplements, medication change over the previous 4 weeks, use of corticosteroids or anticytokine agents, pregnancy, lactation, and a diagnosis of diabetes, decompensated endocrine diseases, infectious diseases (over the previous 4 weeks), demyelinating neurological diseases, peripheral neuropathies, inflammatory articular diseases, systemic autoimmune diseases, severe cardiovascular diseases, malignancy (over the previous year), and severe psychiatric diseases (substance abuse, schizophrenia, psychosis). Nonsteroidal anti-inflammatory agents were suspended $48 \mathrm{~h}$ before collection of blood samples, and all other medications were required to remain unchanged for at least 30 days.

After having executed an Informed Consent Agreement, all women underwent anthropometric assessment, physical exam of pain perception threshold and tender point (TP) count, blood sample collection, filling out of FM impact questionnaire, (FIQ), of Patient Health Questionnaire-9 (PHQ-9), and 3-day dietary record (DR).
Anthropometric assessment was performed by means of body mass index (BMI) consisting of the relation between body weight in kilograms and body height squared in meters: $\mathrm{BMI}=$ weight $/$ height $(\mathrm{m})^{2}[19]$.

The pain threshold was evaluated at the trapezius muscle, using a Fischer algometer (model FDK 20, Wagner Instruments, Greenwich, CT, USA). Each TP was manually palpated with a strength of $4 \mathrm{kgf} / \mathrm{cm}^{2}$ and the response was recorded as positive (with pain) or negative (without pain). In order to measure the pain threshold in the TP located in the right trapezius, the algometer was placed against the skin of the participant and pressed with a strength of $1 \mathrm{kgf} / \mathrm{s}$ until pain onset. Then, the pressure (in $\mathrm{kgf} / \mathrm{cm}^{2}$ ) was recorded and defined as the pain threshold.

Blood samples for measuring serum magnesium $(\mathrm{Mg})$ and calcium $(\mathrm{Ca})$ were drawn in the morning after a 10 12-h fasting. Samples were then placed in ice and centrifuged at $4{ }^{\circ} \mathrm{C}$. Serum was stored at $-80^{\circ} \mathrm{C}$. for later analysis at the UFPR Clinical Analysis Laboratory. For the determination of $\mathrm{Mg}$ and $\mathrm{Ca}$ levels, the Abbott C9000 and/or Ci8200 devices were used. According to the laboratory, reference range values for serum magnesium are $1.6-2.6 \mathrm{mg} / \mathrm{dL}$ and for serum calcium are $8.9-10 \mathrm{mg} / \mathrm{dL}$.

The FIQ was employed to assess the impact of FM in quality of life. This questionnaire covers matters related to functional capacity, professional situation, psychological disorders and physical symptoms. It features a score ranging from 0 to 100 - the higher the score, the greater the impact of FM in quality of life - consequently, the lower the overall health [20].

PHQ-9 is a tool with 9 items used to identify individuals in risk of depression. Its score ranges from 0 to 27, with possible answers variating between 0 (not at all) and 3 (nearly every day). The higher the score, the higher the severity [21].

In order to fill out the Dietary Record, subjects were instructed to take notes on a form including the sort of food and drink they have had and their quantities, three times, in alternate days including 1 day on weekend [22]. Later, all these information was inputed in Avanutri ${ }^{\circ}$ software and the average dietary intake was calculated. According to the DRIs (Dietary Reference Intakes), the EAR (Estimated Average Requirement) for $\mathrm{Mg}$ is 255 $\mathrm{mg} / \mathrm{d}$ for women aged between 19 and 30 years, and 265 $\mathrm{mg} / \mathrm{d}$ for women older than 31 years. For Ca, the EAR is $800 \mathrm{mg} / \mathrm{d}$ for women aged between 19 and 50 years and $1000 \mathrm{mg} / \mathrm{d}$ for women older than 51 years [23].

\section{Statistical analysis}

The analyses were performed by $\mathrm{R}$ software version 3.0.2. (R Development Core Team, 2013). The ShapiroWilk test was performed to assess data normality. To test statistical differences between the two groups, the parametric Student's t-test was performed when data 
conformed to normality and the non-parametric Wilcoxon-Mann-Whitney test was performed for nonnormal data. To establish correlation between the results, the Pearson correlation coefficient was used for data that conformed to normality and Spearman's correlation coefficient was adopted for non-normal data. Significance level was assumed to be $95 \%(p<0.05)$.

\section{Results}

Fifty-three women with FM and 50 women without it participated in this study. Average age and BMI were equivalent in both groups (Table 1). Kilocalorie, carbohydrate and protein intake was substantially lower in the group with FM, as well as intake of magnesium and calcium. No significant differences in serum measurement of these minerals were found in the groups (Table 1).

In the FM group, dietary intake of magnesium and calcium correlated negatively with TP count. This means that the higher the intake of said minerals the lower the TP count, including a positive correlation with pain threshold - the higher the magnesium and calcium intake the higher the pain threshold, therefore, the lower the clinical pain. In the control group, there were no such correlations (Table 2).

The FM group did not have a correlation between levels of serum magnesium and calcium with pain, quality of life and depression risk. In the control group, levels of serum $\mathrm{Mg}$ and $\mathrm{Ca}$ correlated positively with the pain threshold. That is to say that the higher the levels of serum $\mathrm{Mg}$ and $\mathrm{Ca}$, the less acute the pain (Table 3).

\section{Discussion}

Deficiency of vitamins and minerals has been associated to countless clinical conditions, including chronic pain and FM $[2,5]$. In this study, it has been found that dietary intake of magnesium and calcium remained below recommended levels for both groups, which reflects inadequate dietary consumption of said minerals by the Brazilian population [16]. This may be due to the increased consumption of processed food and fast food [13]. In parallel, there is also low intake of foods that are rich in magnesium such as dark-green vegetables, vegetables in general, fish, nuts and seeds, and wholegrain cereals [16], and low intake of foods that are rich in calcium such as milk and dairy, dark-green vegetables, seafood and fish [24].

In spite of the fact that the general population has low dietary intake of foods that are rich in $\mathrm{Mg}$ and $\mathrm{Ca}$, the women with FM who participated in this study had substantially lower dietary intakes than the control group. That has been related to worsening of pain for women with FM. Such assumption was confirmed by the results of this research work, in which dietary intake of $\mathrm{Mg}$ and Ca correlated positively with the pain threshold and negatively with TP count. This means that the lower the intake of said minerals, the lower the pain threshold and higher TP count. That being said, it is necessary to make

Table 1 General characteristics of the participants with fibromyalgia and controls

\begin{tabular}{|c|c|c|c|c|c|}
\hline \multirow[t]{2}{*}{ Variables } & \multicolumn{2}{|c|}{ Fibromyalgia $n=53$} & \multicolumn{2}{|l|}{ Controls $n=50$} & \multirow[t]{2}{*}{$p$-value } \\
\hline & Mean \pm SD & median (min-max) & Mean \pm SD & median (min-max) & \\
\hline Age (years) & $48.13 \pm 8.23$ & $49(26-60)$ & $47.14 \pm 9.93$ & $50(23-60)$ & 0.8018 \\
\hline $\mathrm{BMI}\left(\mathrm{Kg} / \mathrm{m}^{2}\right)$ & $26.58 \pm 4.54$ & $26.79(15.23-38.6)$ & $25.56 \pm 3.62$ & $24.91(19.22-32.95)$ & 0.2123 \\
\hline $\mathrm{TP}(\mathrm{n})$ & $16.2 \pm 1.96$ & $17(11-18)$ & $4.72 \pm 4.04$ & $4(0-14)$ & $<0.001^{*}$ \\
\hline Pain threshold $\left(\mathrm{Kg} / \mathrm{cm}^{2}\right)$ & $2.88 \pm 0.76$ & $2.86(1.73-5.73)$ & $5.46 \pm 1.94$ & $5(2.63-10)$ & $<0.001^{*}$ \\
\hline FIQ score & $71.26 \pm 17.5$ & $76.63(23.85-91.71)$ & $10.64 \pm 12.32$ & $6.21(0-45.32)$ & $<0.001^{*}$ \\
\hline PHQ9 score & $16.41 \pm 5.57$ & $17(4-26)$ & $3.76 \pm 4.31$ & $3(0-19)$ & $<0.001^{*}$ \\
\hline \multicolumn{6}{|l|}{ Dietary intake } \\
\hline Kilocalorie (Kcal) & $1459.97 \pm 351.09$ & $1425.57(872.95-2434.76)$ & $1781.85 \pm 452.77$ & $1699.63(990.56-2926.25)$ & $<0.001^{*}$ \\
\hline Carbohydrate (g) & $190.7 \pm 55.92$ & $178.77(88.36-345.66)$ & $231.24 \pm 67.5$ & $221.49(136.55-463.78)$ & $<0.001^{*}$ \\
\hline Lipids (g) & $99.5 \pm 67.12$ & $77.81(14.24-323.68)$ & $73.46 \pm 40.72$ & $67.75(24.32-251.54)$ & 0.166 \\
\hline Protein (g) & $58.67 \pm 19.91$ & $57.2(27.36-114.68)$ & $70.83 \pm 17.69$ & 67.19 (34.88-104.28) & $0.001^{*}$ \\
\hline Magnesium (mg) & $132.8 \pm 53.76$ & $123.93(30.60-274.65)$ & $155.52 \pm 53.42$ & $158.19(62.25-308.03)$ & $0.03^{*}$ \\
\hline Calcium (mg) & $396.21 \pm 213.06$ & $340.96(82.33-944.27)$ & $538.63 \pm 237.96$ & $518.7(165.65-1332.29)$ & $0.003^{*}$ \\
\hline \multicolumn{6}{|l|}{ Laboratory tests } \\
\hline Magnesium serum (mg/dL) & $2.22 \pm 0.14$ & $2.2(1.8-2.6)$ & $2.2 \pm 0.19$ & $2.2(1.8-2.6)$ & 0.577 \\
\hline Calcium serum (mg/dL) & $9.73 \pm 0.46$ & $9.6(8.8-11.2)$ & $9.64 \pm 0.42$ & $9.7(8.8-10.3)$ & 0.3163 \\
\hline
\end{tabular}

Student's t test was used for the parametric data, and the Wilcoxon Mann-Whitney test was used for the non-parametric data $B M I$ body mass index, TP tender points, FIQ Fibromyalgia Impact Questionnaire, PHQ-9 Patient Health Questionnaire-9 ${ }^{*} P<0.05$ is statistically significant 
Table 2 Relationship between magnesium and calcium intake with the variables: pain, quality of life and risk of depression

\begin{tabular}{|c|c|c|c|c|c|c|c|c|}
\hline \multirow[t]{2}{*}{ Variables } & \multicolumn{2}{|l|}{ TP } & \multicolumn{2}{|c|}{ Pain threshold } & \multicolumn{2}{|l|}{$\mathrm{FIQ}$} & \multicolumn{2}{|l|}{ PHQ9 } \\
\hline & $r$ & $P$ & $r$ & $P$ & $r$ & $P$ & $r$ & $P$ \\
\hline \multicolumn{9}{|c|}{ Magnesium intake } \\
\hline Fibromyalgia & -0.23 & $0.02^{*}$ & 0.25 & $0.01^{*}$ & -0.13 & 0.18 & -0.17 & 0.08 \\
\hline Control & -0.15 & 0.3 & -0.11 & 0.44 & -0.01 & 0.91 & -0.004 & 0.97 \\
\hline \multicolumn{9}{|l|}{ Calcium intake } \\
\hline Fibromyalgia & -0.28 & $0.03^{*}$ & 0.32 & $0.01^{*}$ & -0.07 & 0.59 & -0.17 & 0.2 \\
\hline Control & -0.2 & 0.19 & -0.05 & 0.72 & -0.08 & 0.57 & -0.24 & 0.12 \\
\hline
\end{tabular}

TP tender points, FIQ Fibromyalgia Impact Questionnaire, $P H Q-9$ Patient Health Questionnaire-9

r: Pearson's correlation coefficient for the parametric data or Spearman's correlation coefficient for non-parametric

${ }^{*} P<0.05$ is statistically significant

dietary assessments to adjust the intake of these minerals in order to ensure a healthy, balanced diet that helps reduce pain and painful points in women with FM.

In parallel, although the studied groups had lower dietary intake of magnesium and calcium, that did not reduced these minerals levels in blood samples. Moreover, even though some studies have shown reduced intracellular contents and levels of serum $\mathrm{Mg}$ and high levels of serum $\mathrm{Ca}$ in patients with FM $[7,8,25,26]$, in this study there was no differences in levels of serum $\mathrm{Mg}$ and $\mathrm{Ca}$ between the FM group and the control group. Nevertheless, such fact needs to be further investigated given that studies have adopted different methodologies for analysis of minerals, and present varying levels of serum, erythrocytes, leucocytes, urinary, muscular and hair.

Various authors have stated that plasma concentration of $\mathrm{Mg}$ may not reflect the entire body content of $\mathrm{Mg}$ since the body has mechanisms that maintain constant serum levels within a narrow range of normality $[7,16]$. Additionally, several studies have shown that in spite of concentrations of $\mathrm{Mg}$ in plasma being within normal ranges, the concentration of erythrocyte $\mathrm{Mg}$ was below normal $[9,27]$. Magaldi et al. [28] presented in their

Table 3 Relationship between serum magnesium and calcium levels with the variables: pain, quality of life and risk of depression

\begin{tabular}{|c|c|c|c|c|c|c|c|c|}
\hline \multirow[t]{2}{*}{ Variables } & \multicolumn{2}{|l|}{ TP } & \multicolumn{2}{|c|}{ Pain threshold } & \multicolumn{2}{|l|}{$\mathrm{FIQ}$} & \multicolumn{2}{|l|}{ PHQ9 } \\
\hline & $r$ & $P$ & $r$ & $P$ & $r$ & $P$ & $r$ & $P$ \\
\hline \multicolumn{9}{|c|}{ Magnesium serum } \\
\hline Fibromyalgia & -0.05 & 0.7 & -0.05 & 0.71 & 0.02 & 0.85 & 0.09 & 0.47 \\
\hline Control & -0.07 & 0.6 & 0.4 & $0.004^{*}$ & -0.22 & 0.11 & -0.28 & 0.05 \\
\hline \multicolumn{9}{|l|}{ Calcium serum } \\
\hline Fibromyalgia & 0.08 & 0.4 & 0.13 & 0.18 & 0.03 & 0.73 & -0.006 & 0.95 \\
\hline Control & -0.08 & 0.58 & 0.3 & $0.03^{*}$ & -0.24 & 0.09 & -0.17 & 0.22 \\
\hline
\end{tabular}

TP tender points, FIQ Fibromyalgia Impact Questionnaire, $P H Q-9$ Patient Health Questionnaire-9

r: Pearson's correlation coefficient for the parametric data or Spearman's correlation coefficient for non-parametric

${ }^{*} P<0.05$ is statistically significant study that patients with FM had normal levels of serum $\mathrm{Mg}$ and reduced levels in leucocytes. This confirms the assumption that serum $\mathrm{Mg}$ is a poor predictor of the $\mathrm{Mg}$ status in the body as a whole, and that intracellular analyses are more representative [11, 16, 29-32].

Lower levels of serum calcium (Ca) have not been noticed in women with FM participating in this research work. Although some studies have already found low serum Ca levels in patients with FM, others present normal serum levels but with reduced intracellular concentrations of Ca, such as in leucocytes [28] and hair [3]. This demonstrates that, similarly to what occurs with $\mathrm{Mg}, \mathrm{Ca}$ concentration may be normal in blood but different in the intracellular level [28].

Levels of serum $\mathrm{Mg}$ of women with FM participating in this study have not shown correlation with pain parameters, quality of life and depression risk. Similar results have been found by Sakarya et al. [9]. Sendur et al. [4] found solely correlation of serum $\mathrm{Mg}$ with fatigue severity.

On the other hand, Bagis et al. [7] presented correlation between levels of serum $\mathrm{Mg}$ with VAS (visual analogue scale of pain), TP count, TP index, FIQ, anxiety and depression score, and somatic symptoms in women with FM. Erythrocyte levels of Mg in this study correlated with the same variables, as well as with the pain threshold, fatigue, headache and numbness.

As to levels of serum $\mathrm{Mg}$ and $\mathrm{Ca}$, only the control group presented positive correlation of said minerals with the pain threshold. It is important to notice the role of $\mathrm{Mg}$ in cognitive-affective functions, and studies have shown an improvement in pain and depression parameters after supplementation of $\mathrm{Mg}$ [6]. The Hagenston and Simonetti review study (2014) showed the involvement of neuronal calcium signaling in the processes that mediated chronic pain [33].

Although the minerals analyzed in this study did not correlate with quality of life and depression risk for women with FM, additional research is required to investigate the role of minerals in the symptoms of this 
disease in order to improve the impact of dietary therapies in the quality of life of patients.

The present study has limitations related to serum mineral dosage, which does not seem to be a good predictor of intracellular reserves. In addition, serum Ca values were not corrected by albumin, and it was not possible to measure complementary tests such as ionic Ca, Vitamin D, and PTH (parathyroid hormone), which would help to better analyze the metabolism of these minerals.

Additionally, the three-day food register is a method with intrinsic limitations to its use: it is subjective, requires a high level of motivation and collaboration, requires time, there may be difficulty in estimating portions, and the individual must know the home measures. In parallel, consumption may be altered as the individual knows that it will be assessed, and therefore there may be underreporting of consumption. There may also be regional variations and errors in the software used for data tabulation.

Finally, it is noteworthy that this was a cross-sectional study, which has a number of limitations inherent to its methodology. Therefore, it is very important to conduct clinical trials randomized, with food intervention to lead to a conclusion related to the specific intake of these evaluated nutrients.

\section{Conclusion}

Women with FM had lower dietary intake of magnesium and calcium in comparison with women who did not have the condition. However, serum levels of these nutrients did not turn out to be different between said groups. Lower dietary intake of magnesium and calcium correlated with worsened pain parameters (increased number of TP and decreased pain threshold) in fibromyalgia.

\section{Acknowledgments}

The authors would like to thank the research group: Márcia Maria Marques Teles Lobo, Renata Costa de Miranda and Jéssica Nehring, who contributed to this work. Would like to thank also CAPES, the Nutrition Department, the Rheumatology Department and the Endocrine Division (SEMPR), Department of Internal Medicine, Federal University of Parana (UFPR), Curitiba, PR, Brazil, that made this research possible.

\section{Authors' contributions}

All authors participated sufficiently in the work. They were present during research, evaluation and data collection, as well as in the elaboration of statistical analyzes and in the intellectual contribution related to research and references. All authors assume public responsibility for the content of the article. If requested, authors will provide the data required for review by publishers. All authors read and approved the final manuscript.

\section{Funding}

Not applicable.

\section{Ethics approval and consent to participate}

The Human Research Ethics Committee of Hospital de Clínicas, Universidade Federal do Paraná (CEP-HC/UFPR), manifests itself by the approval of Research Project number 8786 on 27.03.2012, CAAE: 00979612.9.0000.0096. All patients who agreed to participate received and signed an informed consent.

\section{Competing interests}

The authors declare that they have no competing interests.

\section{Author details}

${ }^{1}$ Departamento de Medicina Interna, Universidade Federal do Paraná, Hospital de Clínicas, Rua General Carneiro, 181, Curitiba, PR 80060-900, Brazil. 2Departmento de Nutrição, Universidade Federal do Paraná (UFPR), Curitiba, PR, Brazil. ${ }^{3}$ Estatístico da Universidade Federal do Paraná (UFPR), Curitiba, PR, Brazil. ${ }^{4}$ Endocrine Division (SEMPR), Department of Internal Medicine, Federal University of Parana (UFPR), Curitiba, PR, Brazil. ${ }^{5}$ Departamento de Reumatologia, Universidade Federal do Paraná (UFPR), Curitiba, PR, Brazil.

Received: 27 February 2019 Accepted: 30 October 2019

Published online: 11 December 2019

References

1. Bjørklunda G, Dadar M, Chirumbolo S, Aasethd J. Fibromyalgia and nutrition: therapeutic possibilities? Biomed Pharmacother. 2018;103:531-8.

2. Meleger AL, Froude CK, Walker J. Nutrition and eating behavior in patients with chronic pain receiving long-term opioid therapy. Phys Med Rehabil. 2014;6:7-12.

3. Kim Y-S, Kim K-M, D-J L, Kim B-T, Park S-B, Cho D-Y, et al. Women with fibromyalgia have lower levels of calcium, magnesium, iron and manganese in hair mineral analysis. J Korean Med Sci. 2011;26(10):1253-7.

4. Sendur OF, Tastaban E, Turan Y, UIman C. The relationship between serum trace element levels and clinical parameters in patients with fibromyalgia. Rheumatol Int. 2008;28:1117-21.

5. Batista ED, Andretta A, Miranda RC, Nehring J, Paiva ES, Schieferdecker MEM. Food intake assessment and quality of life in women with fibromyalgia. Rev Bras Reumatol. 2016;56(2):105-10.

6. Pickering G, Morel V, Simen E, Cardot JM, Moustafa F, Delage N, et al. Oral magnesium treatment in patients with neuropathic pain: a randomized clinical trial. Magnes Res. 2011;24(2):28-35.

7. Bagis S, Karabiber M, As I, Tamer L, Erdogan C, Atalay A. Is magnesium citrate treatment effective on pain, clinical parameters and functional status in patients with fibromyalgia? Rheumatol Int. 2013;33:167-72.

8. Joustra ML, Minovic I, Janssens KAM, Bakker SJL, Rosmalen JGM. Vitamin and mineral status in chronic fatigue syndrome and fibromyalgia syndrome: A systematic review and meta-analysis. PLOS ONE. 2017;12(4):e0176631.

9. Sakarya ST, Akyol Y, Bedir A, Canturk F. The relationship between serum antioxidant vitamins, magnesium levels, and clinical parameters in patients with primary fibromyalgia syndrome. Clin Rheumatol. 2011;30:1039-43.

10. Rosanoff A, Weaver CM, Rude RK. Suboptimal magnesium status in the United States: are the health consequences underestimated? Nutr Rev. 2012;70(3):153-64. https://doi.org/10.1111/j.1753-4887.2011.00465.x.

11. Ramalanjaona G. Magnesium in the treatment of fibromyalgia. Altern Med Alert. 2002;5(3):29-32.

12. Neeck G, Riedel W. Thyroid function in patients with fibromyalgia syndrome J Rheumatol. 1992;19:1120.

13. Crosby V, Elin RJ, Twycross R, Mihalyo M, Wilcock A. Therapeutic reviews: magnesium. J Pain Symptom Manag. 2013;45(1):137-44.

14. Werbach MR. Treating chronic fatigue syndrome by repleting mineral deficiencies. Townsend Letter for Doctors and Patients; 2004. p. 247-8.

15. King DE. Inflammation and elevation of C-reactive protein: does magnesium play a key role? Magnes Res. 2009;22(2):57-9.

16. Vannucchi $H$, Monteiro TH. Funções plenamente reconhecidas de nutrientes - magnésio. Bras Int Life Sci Inst Bras (ILSI Brasil). 2010;16:1-19.

17. Bazzichi L, Giannaccini G, Betti L, Fabbrini L, Schmid L, Palego L, et al. ATP, calcium and magnesium levels in platelets of patients with primary fibromyalgia. Clin Biochem. 2008;41:1084-90.

18. Wolfe F, Smythe HA, Yunus MB, Bennett RM, Bombardier C, Godenberg DL, et al. The American College of Rheumatology 1990 criteria for the classification of fibromyalgia. Report of the Multicenter Criteria Committee. Arthritis Rheum. 1990;33:160-72.

19. Global Data Base on Body Mass Index. The international classification of adult underweight, overweight and obesity according to BMI: WHO; 2004. Disponivel em http://apps.who.int/bmi/index.jsp?introPage=intro_3.html. Accessed 24 Feb 2015

20. Marques AP, Santos AMB, Assumpção $A$, et al. Validação da Versão Brasileira do Fibromyalgia Impact Questionnaire (FIQ). Rev Bras Reumatol. 2006;46(1): 24-31 https://doi.org/10.1590/S0482-50042006000100006. 
21. Kroenke K, Spitzer RL, Williams JB. The PHQ-9: validity of a brief depression severity measure. J Gen Intern Med. 2001;16:606-13.

22. Fisberg RM, Marchioni DML, Colucci ACA. Avaliação do consumo alimenta e da ingestão de nutrientes na prática clínica. Arq Bras Endocrinol Metab. 2009:53(5):617-24.

23. Institute of Medicine (IOM). Dietary reference intakes: the essential guide to nutrient requirements. Washington: National Academy Press; 2006.

24. França NAG, Martini LA. Funções Plenamente Reconhecidas de Nutrientes Cálcio. Bras Int Life Sci Inst Bras (ILSI Brasil). 2014;1:1-23.

25. Abraham GE, Flechas JD. Management of fibromyalgia: rationale for the use of magnesium and malic acid. J Nutr Med. 1992;3(1):49-59 https://doi.org/ 10.3109/13590849208997961.

26. Kasim AA. Calcium, magnesium and phosphorous levels in serum of Iraqi. Women with fibromyalgia. Iraqi J Pharm Sci. 2011;20(2):34-7.

27. Rosborg I, Hyellen E, Lidbeck J, Nihlgard B, Gerhardsson L. Trace element pattern in patients with fibromyalgia. Sci Total Environ. 2007;385:20-7.

28. Magaldi M, Moltoni I, Biasi G, Marcolongo R. Changes in intracellular calcium and magnesium ions in the physiopathology of the fibromyalgia syndrome. Minerva Med. 2000;91:137-40.

29. Cox IM, Campbell MJ, Dowson D. Red blood cell magnesium and chronic fatigue syndrome. Lancet. 1991;337(8744):757-60.

30. Romano TJ, Stiller JW. Magnesium deficiency in fibromyalgia syndrome. J Nutr Med. 1994;4(2):165.

31. Eisinger J, Plantamura A, Marie PA, Ayavou T. Selenium and magnesium status in fibromyalgia. Magnes Res. 1994;7:285-8.

32. Weglicki WB. Hypomagnesemia and inflammation clinical and basic aspects. Annu Rev Nutr. 2012;32:55-71.

33. Hagenston AM, Simonetti M. Neuronal calcium signaling in chronic pain Cell Tissue Res. 2014;357(2):407-26.

\section{Publisher's Note}

Springer Nature remains neutral with regard to jurisdictional claims in published maps and institutional affiliations.

Ready to submit your research? Choose BMC and benefit from:

- fast, convenient online submission

- thorough peer review by experienced researchers in your field

- rapid publication on acceptance

- support for research data, including large and complex data types

- gold Open Access which fosters wider collaboration and increased citations

- maximum visibility for your research: over $100 \mathrm{M}$ website views per year

At $\mathrm{BMC}$, research is always in progress.

Learn more biomedcentral.com/submissions 